UNDERGRADUATE RESEARCH IN NATURAL AND CLINICAL SCIENCE AND TECHNOLOGY (URNCST) JOURNAL Read more URNCST Journal articles and submit your own today at: https://www.urncst.com

\title{
iGEM Toronto: Promoting Independent Undergraduate Research in Synthetic Biology at the University of Toronto
}

\author{
Bi-ru Amy Yeung, HBSc, MSc Candidate [1] \\ [1] Department of Physiology, University of Toronto, Toronto, Ontario, Canada M5S 1A8 \\ *Corresponding Author: biruamy.yeung@mail.utoronto.ca
}

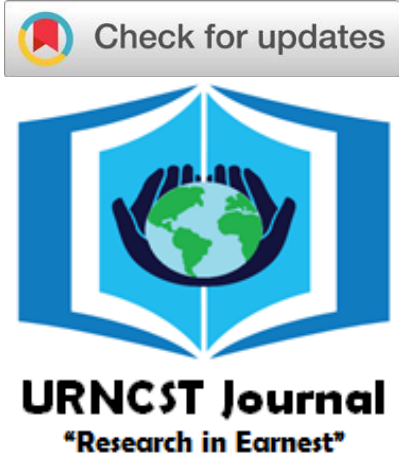

\section{Introduction}

Finding suitable research opportunities can be stressful for undergraduate students. These experiences can ultimately define a student's future career path, decision to attend professional school or graduate programs, or interest in working in a specific industrial stream. With academic and job-related applications, including scholarships and funding opportunities, putting greater emphasis on research experience, students are finding themselves seeking any opportunities made available to them. This can include becoming a volunteer tasked with basic lab tasks (cleaning, making simple solutions, restocking materials, etc.), or administrative duties (stock inventory, ordering reagents, file organization), which although important, do not fully allow them to gain the all the skillsets needed to become a researcher. There are also opportunities for students to take on research projects, but often with the project outline and instructions established and given by an upperclassman or principal investigators (PIs), restricting the student from making big decisions or pursuing independent research. Despite being valuable experience, important skills such as designing or planning an experiment, or troubleshooting problems, remain underdeveloped. This creates a large gap in research ability between finishing undergraduate education and entering graduate school or pursuing a research career. So what opportunities are provided for undergraduate students to be independent researchers?

Keywords: iGEM; iGEM Toronto; synthetic biology; undergraduate; research; publications

\section{Who are We?}

iGEM Toronto may be an answer [1]. International Genetically Engineered Machine (iGEM) is a non-profit foundation that was established by the Massachusetts Institute of Technology (MIT) in 2003 [2]. The organization focuses on promoting and advancing the field of synthetic biology, creating a network amongst students, professors and individuals from the industry [2]. Every year, iGEM headquarters, based in Boston, Massachusetts (MA) [2] organizes and hosts the world's largest synthetic biology competition, the Giant Jamboree, where high school, undergraduate and graduate students from around the world, travel to Boston, MA to present and share their research projects. iGEM Toronto is one of over 300 international teams that partake in the competition, and hosted at the University of Toronto ( $\mathrm{U}$ of $\mathrm{T}$ ), in Toronto, Canada. We define ourselves as an undergraduate research team affiliated with the U of T Engineering Society, providing an opportunity for undergraduate students to pursue independent research with guidance from graduate advisors and associated professors. We pride ourselves in demonstrating that all our achievements, from designing to executing the project, is carried out by undergraduate students. At this competition, to achieve a medal (bronze, silver or gold) a team must convince a panel of judges with different fields

Yeung | URNCST Journal (2019): Volume 3, Issue 6 DOI Link: https://doi.org/10.26685/urnest.132 of expertise that their project has fulfilled a set of medal requirements [3]. Through our hard work and dedication, we have made great accomplishments over the years, winning bronze (2009, 2016 and 2017), silver (2007 and 2015, 2018) and gold (2013) [1]. Moreover, our team is multidisciplinary, involving students from engineering, life science, computer sciences, business and humanity departments. The framework of our team exists as a result of the nature of our team and projects.

Since our establishment in 2005 , we have participated in the competition every year, submitting a new and different project each time. We began as a combined team with the University of Waterloo (named Blue Waters), before becoming independent in 2007. Currently, we have grown to become one of the larger teams across Canada, with a combination of undergraduate students running the project and graduate advisors helping along the way. In the recent years our team size has varied between 30-50 individuals, and our team's organization has evolved to better designate different roles with varying responsibilities. We are composed of two main divisions that are linked together by the President (or Co-Presidents) who overlook both groups; an Executive Administrative team and a Research and Development (RnD) team. The Administrative team is comprised of two teams, one responsible for all internal operations (finances, events 
UNDERGRADUATE RESEARCH IN NATURAL AND CLINICAL SCIENCE AND TECHNOLOGY (URNCST) JOURNAL Read more URNCST Journal articles and submit your own today at: https://www.urncst.com

involving and directly affecting the club, etc.) and the other for external operations (sponsorships, public image, outreach, etc.). The overall responsibility of the Executive Administrative team is to ensure the smooth running of the club, member recruitment and financial stability throughout the year. The $\mathrm{RnD}$ team has the crucial role of producing and executing the research project that will be submitted to the Giant Jamboree. It is composed of three subteams; Wet Lab, Dry Lab and Policy and Practices (PnP). Each of these subteams are led by 2 team leaders and consist of 3-7 general members. The Wet Lab team is responsible for lab work, while the Dry Lab team handles the computational modeling of the project. The PnP team is responsible for investigating the ethical and social implications of our project, which is not often pursued in scientific investigations. This allows our team to explore various problems affecting our society, create biological-based solutions and evaluate how our idea would impact industrial, political, economical and social stakeholders. We require students with different academic backgrounds to be able to develop these different aspects of the project. Students in the sciences are suited for the Wet Lab, those in bioinformatics, mathematics and computer sciences fit well in the Dry Lab team, and those in humanities are perfect for the PnP team. However, we also encourage students to step outside their comfort zone and apply for teams that do not align with their academic background. With the flexibility of our team, this allows students to understand and experience the entirety of developing and executing a project.

\section{Our Focus: Studying in the Field of Synthetic Biology}

Synthetic biology can be described as a field that is a culmination of different subjects, but simply it can be thought or viewed as the subject of biology with an engineering mentality [4]. At U of T, our club has become one of the main avenues for undergraduate exposure and research in this discipline. We provide the resources and expertise to learn and build on existing knowledge, as well as the opportunity to develop the necessary skills to work in the laboratory. We have designed workshops for our members, made to help breakdown the basics of synthetic biology into wet lab, dry lab and bioethical components, similar to the structure of our team. From these workshops, members gain a better understanding of synthetic biology as a whole and have the chance to apply their practical knowledge to an actual project. In addition to these workshops, we are also further developing a trainee program to recruit students for the following year's team. These developments can act as a starting point for the establishment of an introductory program for synthetic biology that will be available for high school and undergraduate students. By doing so, we would be able to teach students the necessary skills to work in this field and help grow and develop the synthetic biology community on campus and across Toronto.

Furthermore, by hosting an iGEM team on campus, we are aiding the development of synthetic biology on a global scale. Part of the competition requirements is to collaborate with other participating iGEM teams, and by doing so we have connected with teams nationally and internationally. Generally, we work with teams that have projects relatable to our own and share data with one another, creating new local and global relationships. We especially facilitate collaborations with the teams hosted across Ontario universities, including McMaster University, University of Waterloo, Queen's University, Western University, University of Guelph, Brock University and University of Ottawa. We meet annually at Ontario iGEM (abbreviated as oGEM), a full day conference hosted at one of the participating universities, where project ideas for the year are shared. This event is held in collaboration with Ontario Genomics, which sends representatives to attend the event and talk about their organization. There have also been special guests from existing synthetic biology corporations, like Synbio Canada, who have attended to talk about their work and future goals for the synbio community across the country. In addition, a North American iGEM ambassador from iGEM HQ also attends our conference, making our event more official and meaningful to the participating teams. We advise each other on project design and execution, possible collaborations, as well as team logistics and funding opportunities. On top of all the academic and iGEM related duties, everyone enjoys meeting other enthusiastic students interested in synthetic biology and making new friends. We also discuss and organize travel plans to go to Boston for the Jamboree, moving as a unit and representing the province of Ontario. Furthermore, there is new discussion across all Canadian teams, high school and undergraduate, of creating an eastern and western Canadian conference, and possibly a nation-wide conference, opening new avenues for collaborations across the country. This will also start a new movement in the field of synthetic biology at an undergraduate level, which has yet to be established in Canada.

\section{The Importance of Academic Publications}

In addition to the physical research experience designing and executing the project, another important component is being able to publish their research findings. Most undergraduates rarely get the chance to publish any research, and if the opportunity arises the process would take longer than the time spent completing undergraduate education. Recently iGEM HQ partnered with PLOS Publications [5] and has provided the opportunities for teams to submit their work, have it immediately reviewed and then possibly published. There are two options for publications; an official research article, with a DOI, that will be published in an issue of PLOS ONE, or as an iGEM report that will be presented in the PLOS iGEM Collection of the year, accessible to iGEM teams and PLOS members, but that will not be officially published [5]. It is a great opportunity, but not all teams are able to meet the requirements to publish their findings, including iGEM Toronto. However, this year we will 
UNDERGRADUATE RESEARCH IN NATURAL AND CLINICAL SCIENCE AND TECHNOLOGY (URNCST) JOURNAL Read more URNCST Journal articles and submit your own today at: https://www.urncst.com

have the privilege of working with the Undergraduate $\mathrm{Re}$ search in Natural and Clinical Science and Technology (URNCST) Journal, providing another opportunity for our team and other undergraduates at $\mathrm{U}$ of $\mathrm{T}$ to publish scientific work.

Understanding that the URNCST Journal targets publishing undergraduate research perfectly aligns with iGEM Toronto's focus on promoting undergraduate research, highlighting the amazing and hidden talents of undergraduate students. Through this collaboration we hope to inspire students to pursue undergraduate research in their respective fields and publish their work. We want to encourage students interested in research to think of and conduct meaningful project work that is worthy of being published, rather than only completing simple lab duties. With this collaboration, we are providing undergraduate students with the opportunity to publish by hosting our very first abstract competition. Our competition is open to undergraduate students in any level and program at the University of Toronto, providing them with the opportunity to submit an abstract relating to genetic engineering of bacterial systems in clinical applications. Students with the highest-quality abstracts will be selectively published in an abstract book in a future issue of the URNCST Journal. Writing an abstract to summarize a project demands participants to think about the design of the project, which is the first step to any research. With this platform we can aid our members and other students in developing their scientific writing skills, specifically for work intended for publication. We want to encourage students to take charge of their work, understand the details and make their own decisions in project execution.

\section{Making a Difference}

Undergraduate research is gradually becoming more important in an academic and industrial setting, and yet impactful research positions are limited and extremely competitive, especially at the University of Toronto. This situation is arguably also true at many other academic institutions across the world.. With this collaboration we hope to change the perception of undergraduate research to students, professors and the working industry. iGEM Toronto really strives to provide this opportunity for students and the URNCST Journal will allow us to publish our work professionally. Our team hopes that with this new beginning we can make a dif- ference to those pursuing undergraduate research and highlight undergraduate students making graduate level achievements.

\author{
List of Abbreviations Used \\ iGEM: International Genetically Engineered Machine \\ MIT: Massachusetts Institute of Technology \\ MA: Massachusetts \\ PI: Principal Investigator \\ PnP: Policy and Practices \\ RnD: Research and Development \\ U of T: University of Toronto \\ URNCST: Undergraduate Research in Natural and Clinical \\ Science and Technology
}

\section{Conflicts of Interest}

The author declares that they have no conflict of interest.

\section{Authors' Contributions}

BAY: composed the entire editorial based on past and current experience as a member of iGEM Toronto.

\section{Acknowledgements}

I wish to acknowledge all the previous and current members of the iGEM Toronto team, who have done amazing work to establishing the team and provided me the information needed to write the article.

\section{Funding}

This editorial was not funded.

\section{References}

[1] iGEM Toronto [internet]. iGEM Toronto [cited March 25, 2019]. Available from: http://igemtoronto.ca/ [2] About iGEM [internet]. iGEM 2019 [cited March 25, 2019]. Available from: https://2019.igem.org/About [3] iGEM Medals [internet]. iGEM 2019 [cited March 25, 2019]. Available from: https://2019.igem.org/Judging/Medals

[4] Cameron DE, Bashor CJ, Collins JJ. A brief history of synthetic biology. Nature Review Microbiology. 2014 May;12(5):381-90. http://dx.doi.org/10.1038/nrmicro3239 [5] PLOS at the iGEM 2017 Giant Jamboree [internet]. PLOS [cited March 25, 2019]. Available from: https://www.plos.org/igem

\section{Article Information}

Managing Editor: Jeremy Y. Ng

Article Dates: Received Mar 25 19; Accepted Jun 15 19; Published Jun 2719

\section{Citation}

Please cite this article as follows:

Yeung BA. iGEM Toronto: Promoting independent undergraduate research in synthetic biology at the University of Toronto. URNCST Journal. 2019 Jun 27: 3(6). https://urncst.com/index.php/urncst/article/view/132

DOI Link: https://doi.org/10.26685/urncst.132 
UNDERGRADUATE RESEARCH IN NATURAL AND CLINICAL SCIENCE AND TECHNOLOGY (URNCST) JOURNAL

Read more URNCST Journal articles and submit your own today at: https://www.urncst.com

\section{Copyright}

(C) Bi-ru Amy Yeung. (2019). Published first in the Undergraduate Research in Natural and Clinical Science and Technology (URNCST) Journal. This is an open access article distributed under the terms of the Creative Commons Attribution License (https://creativecommons.org/licenses/by/4.0/), which permits unrestricted use, distribution, and reproduction in any medium, provided the original work, first published in the Undergraduate Research in Natural and Clinical Science and Technology (URNCST) Journal, is properly cited. The complete bibliographic information, a link to the original publication on http://www.urncst.com, as well as this copyright and license information must be included.
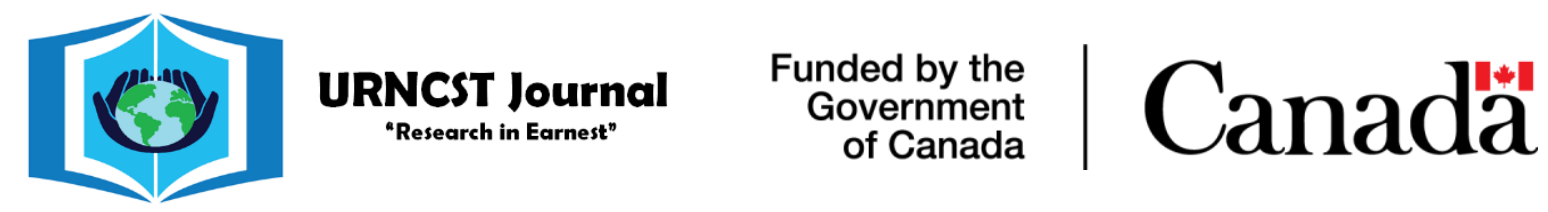

Do you research in earnest? Submit your next undergraduate research article to the URNCST Journal!

| Open Access | Peer-Reviewed | Rapid Turnaround Time | International | | Broad and Multidisciplinary | Indexed | Innovative | Social Media Promoted |

Pre-submission inquiries? Send us an email at info@urncst.com | Facebook, Twitter and LinkedIn: @URNCST

Submit YOUR manuscript today at https://www.urncst.com! 